\title{
Soil chemistry and nutrient concentrations in perennial ryegrass as influenced by gypsum and carbon amendments
}

\author{
M. K. Walia ${ }^{1}$ and W.A. Dick ${ }^{2 *}$ \\ ${ }^{1}$ Montana State University/ Eastern Agricultural Research Center, Sidney, MT, USA 59270 \\ 2School of Environment and Natural Resources, The Ohio State University/The Ohio Agricultural Research and \\ Development Center, Wooster, OH, USA 44691 \\ *Corresponding author: dick.5@osu.edu
}

\begin{abstract}
Plant growth is affected by soil properties that can be improved through addition of amendments and other management practices. Use of gypsum as a soil amendment for improving agricultural yields, and soil and water quality is increasing, but knowledge is lacking on how it affects the soil's chemical properties and plant growth. This greenhouse study measured changes in soil chemistry, growth and nutrient uptake response of ryegrass (Lolium perenne) grown in two contrasting soil types amended with crop residues, glucose, and gypsum. The soil chemical properties, biomass yield, and elemental composition of ryegrass shoots and roots were evaluated. Residue addition significantly increased total soil $\mathrm{N}$ and $\mathrm{pH}$, and glucose significantly lowered soil $\mathrm{pH}$. Gypsum significantly increased $\mathrm{pH}$ in the $25-40 \mathrm{~cm}$ layer only and exchangeable $\mathrm{Ca}$ in all layers, and decreased Bray P-1 in the surface layer by $40 \%$. No significant effects were observed in above-ground ryegrass biomass with addition of inputs. Compared to the untreated soil, gypsum increased $\mathrm{Ca}$ and $\mathrm{S}$ uptake by 50 and $259 \%$, respectively, in the last harvest and $\mathrm{Ca}, \mathrm{S}$ and $\mathrm{Mo}$ in roots by 77,175 , and $18 \%$. Addition of residues and gypsum improved soil chemical properties, nutrient availability, and uptake, but not ryegrass yield.
\end{abstract}

Keywords: Glucose, Gypsum, residues, ryegrass, ryegrass nutrient concentrations, soil chemical properties 


\section{Introduction}

To meet the sustainable demand for food, fuel, and fiber for the world's growing human population, it is important to increase the area under production or increase the productivity of agricultural soils. Rapid depletion in soil fertility is often the primary reason for the decline in crop production. Sustainability of soil and crop production is a function of soil physical, chemical, and biological properties. Small changes in these properties can cause large impacts on crop growth and development, and thus crop yields. To maintain or improve soil properties for continuous long-term agricultural production, it is important to add inputs or soil amendments.

Organic amendments, such as crop residues, are viable means of improving the productivity of soils (Ogbodo, 2011). However, this requires judicious use of these materials to enhance productivity without compromising long-term sustainability. Agricultural production generates a large amount of crop residues. Crop residues are a valuable source of organic matter for most agricultural soils, and contain both macronutrients (e.g., N, P, K, S, and Ca) and micronutrients (e.g., Fe, $\mathrm{Zn}, \mathrm{Mg}$, and $\mathrm{Mn}$ ) essential for plant growth and development. Crop residues returned to the soil improve soil quality and productivity through favorable effects on soil properties such as plant available water holding capacity, cation exchange capacity, and the stimulation of beneficial microorganisms (Saroa and Lal, 2003).

Soil organic carbon (SOC) concentrations in soil depend on the amounts of residue applied to soil, their chemical composition, and decomposition rate (Martens, 2000b). As the amounts of residue applied to soil increased, soil organic matter and $\mathrm{N}$ were increased significantly in the top $15 \mathrm{~cm}$ soil layer after four wheat-fallow cycles (Black, 1973). $\mathrm{NaHCO}_{3}$-soluble $\mathrm{P}$ was also increased, and this increase was independent of $\mathrm{P}$ fertilization. Exchangeable $\mathrm{K}$ was increased as the residue level increased following one year of fallow in Montana (Black, 1973).

Glucose is an organic material that decomposes quickly. It can improve soil physical properties such as aggregation, and biological properties such as microbial biomass carbon, enzyme activities, and microbial growth (Amato and Ladd, 1992). In contrast, crop residues degrade much more slowly and stimulate microbial activity, at least in the short term, to a lesser degree than glucose. Thus, the choice of these two organic materials spans the range of most types of organic amendments expected to be applied to soil. Gypsum is often used as a soil amendment. Application of gypsum (calcium sulfate dihydrate, $\mathrm{CaSO}_{4} \cdot 2 \mathrm{H}_{2} \mathrm{O}$ ) to agricultural soils has been practiced for more than 250 years, and is one of the earliest forms of fertilizers used in the United States (Chen and Dick, 2011). The Clean Air Act Amendments of 1990 mandated that electricity-producing utilities install systems for removal of flue gases (e.g. $\mathrm{SO}_{2}$ ) that are generated during the burning of coal. The initial reaction that occurs during $\mathrm{SO}_{2}$ removal is the formation of calcium sulfite, which upon forced oxidation results in a high purity synthetic gypsum product known as flue gas desulfurization (FGD) gypsum. This product is available for drywall manufacturing or for agricultural applications. A total of about 34 million tons of FGD gypsum was produced by utilities (American Coal Ash Association, 2016).

Gypsum is moderately soluble in water (solubility 2.5 $\mathrm{g} \mathrm{L}^{-1}$ ) and this allows the release of $\mathrm{Ca}^{2+}$ and $\mathrm{SO}_{4}{ }^{2-}$ into the soil solution. Gypsum is thus a good source of both calcium and sulfur, two essential macro-elements needed for plant nutrition (Shainberg et al., 1989). Gypsum has also been used to improve alkaline and saline soils and is one of the most widespread amendments 
in amelioration of alkali soils (Dick et al., 2006; Shainberg et al., 1989). Other chemical properties improved by gypsum include the amelioration of subsoil acidity and aluminum toxicity (Sumner, 1993; Farina et al., 2000b).

Because FGD gypsum, like other sources of gypsum, has the potential to improve soil fertility and quality, it can also increase agricultural productivity (Dick et al., 2006; Batool et al., 2015). Syed-Omar and Sumner (1991) observed that gypsum amendment at $2 \mathrm{t}$ $\mathrm{ha}^{-1}$ reduced topsoil exchangeable $\mathrm{Mg}$ and $\mathrm{K}$ in Georgia and also increased the yields of alfalfa and sorghum. Yield of both crops, however, were adversely affected above an application rate of $5 \mathrm{tha}^{-1}$.

Gypsum is readily available throughout the world as a by-product of flue gas scrubbing. It is also mined in 80 countries. The United States is the production leader and accounts for $15 \%$ of the total world output (Lindau et al., 1998). Moreover, enormous amounts of crop residues are also produced annually by agriculture in United States and reapplied back to the land. Research is needed to evaluate their combined impact on plant growth and also soil chemistry as it is a practice that is becoming more prevalent. In this study, we also treated the soil with glucose to evaluate the interaction of a rapidly available $\mathrm{C}$ source with gypsum, in contrast to the more slowly released $\mathrm{C}$ from plant residues. Specifically, the objectives of this study were to evaluate the effect of treatments (corn residue, glucose and gypsum), on soil chemical properties and on nutrient concentrations and yield of above and below ground biomass of perennial ryegrass (Lolium perenne) grown in two soils of Ohio.

\section{Material and Methods}

\subsection{Experimental setup}

A greenhouse experiment was conducted at The Ohio Agricultural Research and Development Centre of The Ohio State University, Wooster, Ohio, USA. A Wooster silt loam soil (fine-loamy, mixed, mesicTypicFragiudalfs) and a Hoytville clay loam soil (fine, illitic, mesicMollicEpiaqualfs) were collected from university fields located near Wooster and Custar, Ohio, USA, respectively. Soils were collected from the top $30 \mathrm{~cm}$ in the summer of 2013.

Each soil was screened through a 2-mm sieve and then mixed thoroughly before selected soil properties were measured (Table 1). Soil pH was measured using a 1:1 ratio of soil to deionized water (Watson and Brown, 1998), soil texture by the hydrometer method (Day, 1965), total $\mathrm{C}$ and $\mathrm{N}$ using high temperature combustion (Nelson and Sommers, 1996), Bray P-1 by the method of Frank et al. (1998), and exchangeable bases $\left(\mathrm{Ca}, \mathrm{K}\right.$, and $\mathrm{Mg}$ ) by extraction with $1 \mathrm{M} \mathrm{NH}_{4} \mathrm{OAC}$ (Warncke and Brown, 1998).

Table 1. Selected soil chemical characteristics before application of treatments.

\begin{tabular}{|c|c|c|}
\hline \multirow[b]{2}{*}{ Parameter } & \multicolumn{2}{|c|}{ Soil } \\
\hline & Wooster & Hoytville \\
\hline $\mathrm{pH}$ & 6.15 & 6.80 \\
\hline Texture Classification & Silt loam & Clay loam \\
\hline Sand $(\%)$ & 16 & 22 \\
\hline Silt (\%) & 59 & 30 \\
\hline Clay $(\%)$ & 25 & 48 \\
\hline Carbon $(\%)$ & 0.72 & 2.14 \\
\hline Nitrogen $(\%)$ & 0.09 & 0.24 \\
\hline Bray P-1 (mg/kg) & 6.5 & 22.2 \\
\hline \multicolumn{3}{|c|}{$\mathrm{NH}_{4} \mathrm{OAc}$ Extracted $(\mathrm{mg} / \mathrm{kg})$} \\
\hline $\mathrm{Ca}^{2+}$ & 1140 & 2730 \\
\hline $\mathrm{Mg}^{2+}$ & 184 & 365 \\
\hline $\mathrm{K}^{+}$ & 72.9 & 254 \\
\hline $\mathrm{CEC}^{\mathrm{a}}(\mathrm{cmol}(+) / \mathrm{kg})$ & 7.4 & 19.2 \\
\hline
\end{tabular}

${ }^{\mathrm{a}} \mathrm{CEC}=$ cation exchange capacity. 
The materials applied as soil treatments were crop (corn) residues, gypsum, and glucose. Corn residues were collected from the field and dried in an oven at $60{ }^{\circ} \mathrm{C}$ before being ground to pass a $2 \mathrm{~mm}$ mesh sieve. Glucose and gypsum were obtained from Fisher Scientific. The materials were analyzed for total $\mathrm{C}$ and $\mathrm{N}$ (high temperature combustion) using a VARIO Max C-N analyzer. Total P, Ca, K, Fe, Mg, Mo, Na, B, S, and $\mathrm{Zn}$ concentrations (Table 2) were measured by microwave-assisted nitric acid digestion followed by inductively coupled plasma - atomic emission spectrometry (ICP-AES) (USEPA 3051). All soil and treatment materials were analyzed in the STAR Laboratory, OARDC, Wooster, OH (http://www.oardc.ohio-state. edu/starlab). Soil columns (dimensions $60 \mathrm{~cm}$ long and $20 \mathrm{~cm}$ diameter) were made from polyvinyl chloride pipe (Figure 1). The bottom of each column was fixed within a wooden box ( $20 \mathrm{~cm}$ x $20 \mathrm{~cm}$ square) supported by two wooden blocks at the bottom. A hole was drilled in the center of this wooden box and a rubber stopper was inserted into the hole to facilitate leachate collection.

Table 2. Concentration of elements in the inputs added to soil.

\begin{tabular}{lccc}
\hline Element & Crop Residues & Glucose & Gypsum \\
\hline $\mathrm{N}$ & 0.90 & $\mathrm{ND}^{\mathrm{b}}$ & $\mathrm{ND}$ \\
$\mathrm{C}$ & 45.0 & 39.9 & $\mathrm{ND}$ \\
& & & \\
$\mathrm{B}$ & 0.99 & $<0.35$ & 14.3 \\
$\mathrm{Ca}$ & 2922 & $<15.5$ & 196,735 \\
$\mathrm{Fe}$ & 425 & 29.8 & 1.00 \\
$\mathrm{~K}$ & 8560 & $<90.3$ & 223 \\
$\mathrm{Mg}$ & 1915 & $<1.65$ & 6.58 \\
$\mathrm{Mo}$ & 0.48 & 0.73 & 1.13 \\
$\mathrm{Na}$ & 25.7 & $<20.9$ & 52.0 \\
$\mathrm{P}$ & 654 & $<8.32$ & $<8.32$ \\
$\mathrm{~S}$ & 971 & $<13.0$ & 154,450 \\
$\mathrm{Zn}$ & 41.5 & $<0.78$ & $<0.78$ \\
\hline
\end{tabular}

${ }^{\mathrm{a} C r o p}$ residue was applied as corn.

${ }^{\mathrm{b} N D}$, not determined.

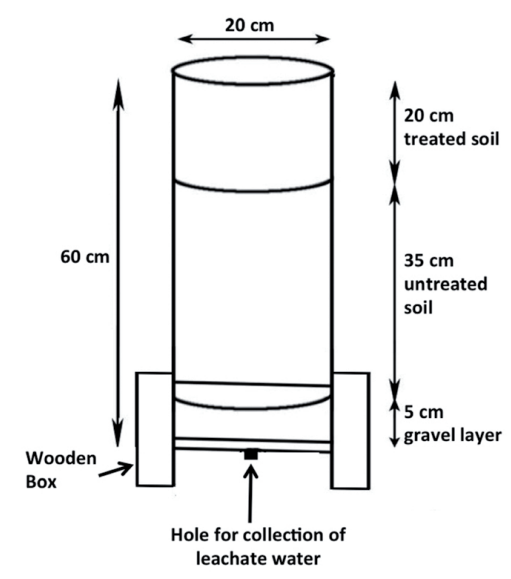

Figure 1. Soil column made from polyvinyl chloride

The columns were filled first with a $5 \mathrm{~cm}$ layer of gravel. Over the gravel the soil was placed to a depth of 35 $\mathrm{cm}$, except for the control/untreated columns that were filled to a depth of $55 \mathrm{~cm}$. The top $20 \mathrm{~cm}$ layer of the treated columns consisted of soil treated with corn resi-

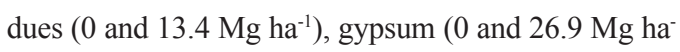
$\left.{ }^{1}\right)$, and glucose ( 0 and $\left.4.5 \mathrm{Mg} \mathrm{ha}^{-1}\right)$. The corn residues were mixed into the soil at the time the columns were filled with soil. The gypsum was applied in four equal applications. The first application of $6.7 \mathrm{Mg} \mathrm{ha}^{-1}$ was at the time the columns were filled with soil. The second, third and fourth applications of gypsum were applied one, three and five months after ryegrass was sown. Similarly, glucose was initially applied at a rate of 2.25 $\mathrm{Mg} \mathrm{ha}^{-1}$ at the time the soil columns were filled and then a second equal application was made three months after ryegrass was sown. There were four replicates of each soil. This treatment/combination yielded a total of 96 experimental units. The experiment was a complete block factorial design.

An experimental timeline providing a complete description of all measurements made during the experiment is provided in Figure 2. This paper reports measurements of plant growth and soil chemistry data. 

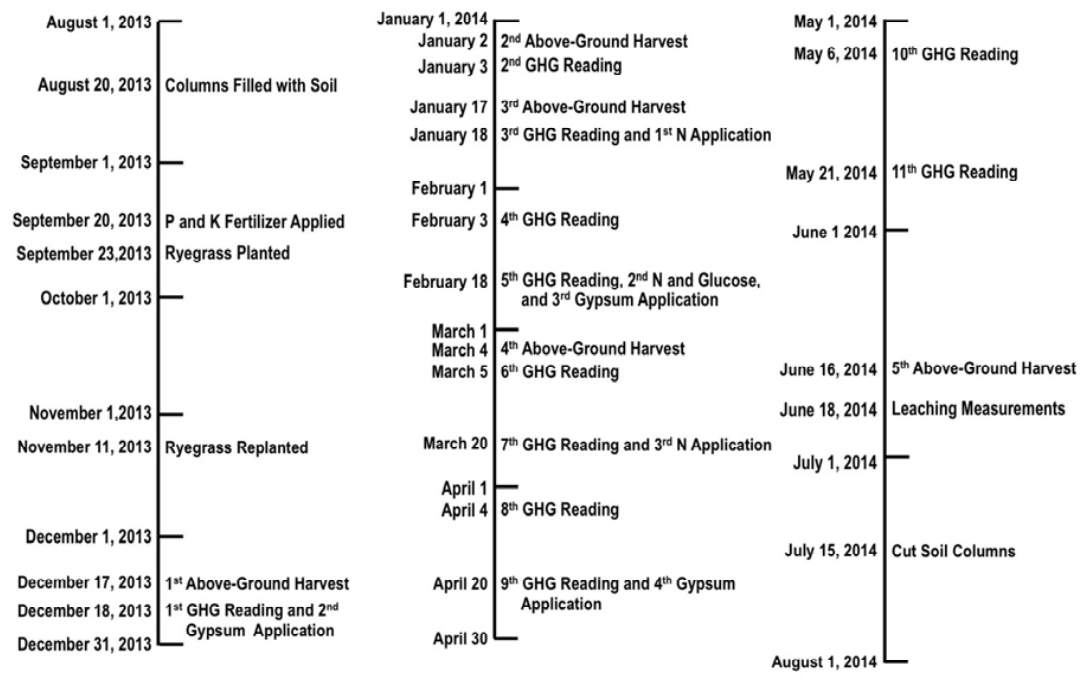

Figure 2. Timeline for the greenhouse experiment.

The soil columns were seeded in September with perennial ryegrass at the rate of $27 \mathrm{~kg} \mathrm{ha}^{-1}$. Perennial ryegrass (Lolium perenne) was selected due to its rapid growth and fibrous root system. Due to poor stand establishment, the columns were reseeded in November and were allowed to grow before the first above ground biomass harvest was completed in December. Fertilizers N, P and K were applied at rates of 168, 25, and $75 \mathrm{~kg} \mathrm{ha}^{-1}$. Phosphorus (single super phosphate) and potassium (muriate of potash) were applied at planting and nitrogen (urea) was applied in three equal doses (56 kg ha ${ }^{-1}$ each) two, three, and four months after planting. The seed and fertilizers rates were chosen based upon NRCS-Ohio recommendations for grasses grown in Ohio.

The temperature in the greenhouse was maintained at $22{ }^{\circ} \mathrm{C} / 18{ }^{\circ} \mathrm{C}$ (day/night) throughout the experiment period. A total of five above-ground ryegrass biomass harvests were made 30, 45, 60, 105 and 210 days after the ryegrass was planted. All harvests were oven-dried at $60{ }^{\circ} \mathrm{C}$ for five days and weighed.
The root mass was also recovered from each soil column at the end of experiment, washed, and then ovendried at $60{ }^{\circ} \mathrm{C}$ for five days. The first and last aboveground biomass harvests and roots of ryegrass were ground to pass through a 2-mm mesh screen and then analyzed for nutrient concentration. Parameters measured were total $\mathrm{C}$ and $\mathrm{N}$ (high temperature combustion using a VARIO Max C-N analyzer) and $\mathrm{P}, \mathrm{K}, \mathrm{Ca}$, $\mathrm{Mg}, \mathrm{S}, \mathrm{Al}, \mathrm{B}, \mathrm{Cu}, \mathrm{Fe}, \mathrm{Mn}, \mathrm{Mo}, \mathrm{Na}$ and $\mathrm{Zn}$ concentrations by perchloric acid digestion followed by inductively coupled plasma (ICP) emissions spectrometry. Analyses were performed at the STAR Laboratory.

\subsection{Soil sampling}

Soil materials were collected at the end of the experiment i.e. almost one year after addition of amendments in soil, by cutting the soil columns into five sections representing soil layers of 0-2, 2-4, 4-10, 10 25 and $25-40 \mathrm{~cm}$. The soil samples were air-dried and sieved by hand through a $2-\mathrm{mm}$ screen. Chemical parameters measured included total $\mathrm{N}, \mathrm{P}, \mathrm{K}, \mathrm{Ca}, \mathrm{Mg}, \mathrm{pH}$. 
Analytical methods included high temperature combustion (N) using a VarioMax $\mathrm{C}-\mathrm{N}$ analyzer, soil $\mathrm{pH}$ (1:1 soil to deionized water ratio) (Watson and Brown, 1998), Bray P-1 for P (Frank et al., 1998), and exchangeable $\mathrm{K}^{+}, \mathrm{Ca}^{2+}$ and $\mathrm{Mg}^{2+}$ using $1 \mathrm{M}$ $\mathrm{NH}_{4} \mathrm{OAc}$ as extractant (Warncke and Brown, 1998). Cation exchange capacity $(\mathrm{cmol}(+) / \mathrm{kg})$ was calculated by a summation of the exchangeable $\mathrm{K}^{+}, \mathrm{Ca}^{2+}$ and $\mathrm{Mg}^{2+}$ analyzed in the dried soil after leaching was completed.

\subsection{Statistical analysis}

Data was analyzed using the general linear model (GLM) with Tukey's multiple comparisons (Minitab Inc., 2007). Means were separated using the ANOVA when the F-test for treatment was significant. Statistical significance was evaluated at $p \leq 0.10$. Factors in the ANOVA model were glucose, gypsum, residue, soil, and glucose interaction with gypsum, glucose interaction with residue, glucose interaction with soil.

Table 3. Probability values of various interactions on soil total N, pH, Bray P-1, exchangeable $\mathrm{Ca}$, and $\mathrm{Mg}$ and cation exchange capacity (CEC).

\begin{tabular}{|c|c|c|c|c|c|}
\hline \multirow[b]{2}{*}{ Factors } & \multicolumn{5}{|c|}{ Soil Depth $(\mathrm{cm})$} \\
\hline & $0-2$ & $2-4$ & $4-10$ & $10-25$ & $25-40$ \\
\hline \multicolumn{6}{|l|}{ Total N } \\
\hline Residue x Gypsum & 0.601 & 0.951 & 0.030 & 0.039 & 0.103 \\
\hline Gypsum $x$ Soil & $0.009^{\mathrm{a}}$ & 0.137 & 0.066 & 0.903 & 0.571 \\
\hline \multicolumn{6}{|l|}{$\mathrm{pH}$} \\
\hline Residue x Gypsum & 0.002 & 0.012 & 0.169 & 0.845 & 0.573 \\
\hline Glucose x Gypsum & 0.926 & 0.037 & 0.001 & 0.001 & 0.001 \\
\hline Glucose $x$ Soil & 0.042 & 0.053 & 0.006 & 0.001 & 0.000 \\
\hline Gypsum x Soil & 0.016 & 0.025 & 0.021 & 0.006 & 0.291 \\
\hline \multicolumn{6}{|l|}{ Bray P-1 } \\
\hline Residue $\times$ Soil & 0.496 & 0.264 & 0.014 & 0.037 & 0.030 \\
\hline Glucose $x$ Soil & 0.923 & 0.390 & 0.075 & 0.012 & 0.017 \\
\hline \multicolumn{6}{|l|}{ Exchangeable Ca } \\
\hline Gypsum $x$ Soil & 0.078 & 0.736 & 0.024 & 0.032 & 0.339 \\
\hline \multicolumn{6}{|l|}{ Exchangeable Mg } \\
\hline Glucose $x$ Soil & 0.459 & 0.098 & 0.012 & 0.148 & 0.580 \\
\hline \multicolumn{6}{|l|}{ CEC } \\
\hline Residue x Glucose & 0.398 & 0.793 & 0.031 & 0.007 & 0.597 \\
\hline Gypsum $x$ Soil & 0.088 & 0.595 & 0.006 & 0.045 & 0.280 \\
\hline
\end{tabular}

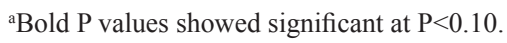




\section{Result}

\subsection{Soil chemical properties}

Total $\mathrm{N}$ in soil as affected with various treatments ranged from $0.159-0.196 \%$. Crop residues significantly increased total $\mathrm{N}$ in the 2-4, 4-10, 10-25 and 25-40 cm soil layers by $4.8,6.1,5.6$ and $3.1 \%$, respectively, as compared to the control. Glucose addition did not have any significant effect on total $\mathrm{N}$ content in soils. Total $\mathrm{N}$ was significantly reduced by gypsum in the $0-2,4-10$ and $10-25 \mathrm{~cm}$ soil layers as compared to the control.

Interaction of gypsum with soil type was significant for total $\mathrm{N}$ for the $0-2$ and $4-10 \mathrm{~cm}$ soil layers (Table 3). Total $\mathrm{N}$ was significantly higher in Hoytville soil than Wooster soil and addition of gypsum to Wooster soil reduced total $\mathrm{N}$ content significantly in both soil layers. Interaction of gypsum with residue was significant for the 4-10 and 10-25 cm soil layers (Table 3). Addition of residue alone resulted in significantly higher $\mathrm{N}$ content in both soil layers as compared to gypsum alone and the untreated control only in the $10-25 \mathrm{~cm}$ soil layer. However, in the $4-10 \mathrm{~cm}$ soil layer, the combined application of gypsum along with residue resulted in significantly lower soil total $\mathrm{N}$ than residue alone, but significantly higher soil total $\mathrm{N}$ than gypsum alone. Soil $\mathrm{pH}$ ranged from 6.12-6.68. In general, soil $\mathrm{pH}$ increased with the addition of crop residue. A significant increase was observed in the top $10 \mathrm{~cm}$ (i.e. in the $0-2$, 2-4 and $4-10 \mathrm{~cm}$ soil layers) by $0.22,0.30$ and 0.20 $\mathrm{pH}$ units, respectively $(\mathrm{P}<0.10)$ (Figure 3). Glucose addition also significantly increased $\mathrm{pH}$ by $0.16 \mathrm{pH}$ units in the surface $(0-2 \mathrm{~cm})$ soil layer as compared to the control. In contrast, soil $\mathrm{pH}$ was significantly decreased by glucose below $4 \mathrm{~cm}$ (i.e. in the 4-10, 1025 and $25-40 \mathrm{~cm}$ soil layers) by $0.22,0.37$ and $0.45 \mathrm{pH}$ units, respectively $(\mathrm{P}<0.10)$ (Figure 3$)$. Addition of gypsum increased soil $\mathrm{pH}$ significantly in the $25-40 \mathrm{~cm}$ soil layer by $0.26 \mathrm{pH}$ units $(\mathrm{P}<0.10)$ (Figure 3 ).
The interaction of residue with gypsum on soil $\mathrm{pH}$ was significant for only 2 soil layers, i.e. the 0-2 and 2-4 cm layers (Table 3). The addition of residue and gypsum alone or in combination increased soil $\mathrm{pH}$ significantly as compared to the control. The glucose by gypsum interaction was significant for all soil layers except the 0-2 cm layer (Table 3). Addition of glucose alone reduced soil $\mathrm{pH}$ significantly as compared to all other treatments in the $10-25$ and $25-40 \mathrm{~cm}$ soil layers, while in the 4-10 cm soil layer, $\mathrm{pH}$ was lowered significantly with glucose alone compared to the control.

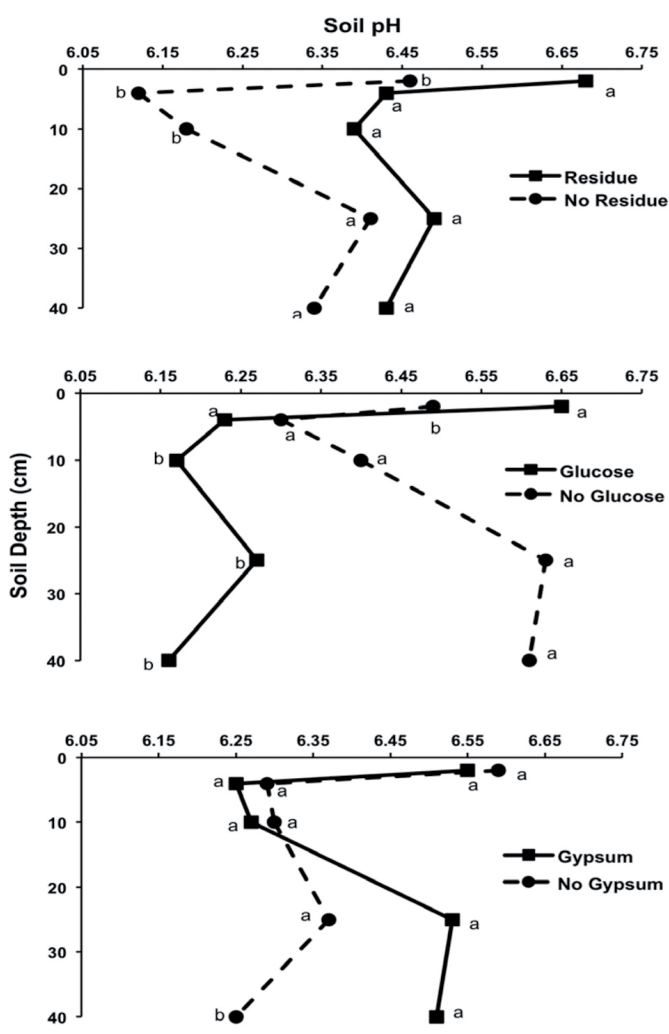

Figure 3. Effect of residue ( 0 and $\left.13.4 \mathrm{Mg} \mathrm{ha}^{-1}\right)$, glucose $(0$ and 4.5 $\left.\mathrm{Mg} \mathrm{ha}^{-1}\right)$, and gypsum (0 and 26.9 $\left.\mathrm{Mg} \mathrm{ha}^{-1}\right)$ on $\mathrm{pH}$ in different soil depths. Means with the same letter within the same depth are statistically similar $(\mathrm{P}<0.10)$. 
Interaction of glucose with soil types for soil $\mathrm{pH}$ was significant $(\mathrm{P}<0.10)$ for all soil layers (Table 3$)$. Soil $\mathrm{pH}$ increased significantly in the $0-2 \mathrm{~cm}$ soil layer with addition of glucose to the Wooster soil but not the Hoytville soil. However, in layers below $4 \mathrm{~cm}$, the $\mathrm{pH}$ of Hoytville soil only was decreased significantly with glucose addition as compared to no addition, and no significant effects were observed in the $\mathrm{pH}$ of the Wooster soil.

Interaction of gypsum with soil type was significant for all soil layers except the 25-40 cm layer. Gypsum addition did not affect the Wooster soil $\mathrm{pH}$ significantly. However, addition of gypsum to the Hoytville soil significantly increased soil $\mathrm{pH}$ in soil layers $2-4$, 4-10, and 10-25 cm compared to the untreated Hoytville soil. No significant effect of gypsum on soil $\mathrm{pH}$ was observed in the $0-2 \mathrm{~cm}$ soil layer.

Bray P-1 level decreased with soil depth in all treatments and varied from $60-101 \mathrm{mg} \mathrm{kg}^{-1}$ in the top layer of soil. The addition of residue increased the Bray P-1 levels, but significant increases were observed only in soil layers below $10 \mathrm{~cm}$ (i.e. the $10-25$ and $25-40 \mathrm{~cm}$ soil layers) by 34 and $21 \%$ compared to the control. Addition of glucose decreased Bray P-1 levels in soil significantly in the $25-40 \mathrm{~cm}$ soil layer (by $15 \%$ ) compared to the control $(\mathrm{P}<0.10)$. Addition of gypsum generally reduced Bray P-1 but was significant $(\mathrm{P}<0.10$, $40 \%$ reduction) only in the surface $(0-2 \mathrm{~cm})$ layer.

The interaction of residue and glucose with soil types were significant below $4 \mathrm{~cm}(\mathrm{P}<0.10)$ (Table 3). Residue addition increased and glucose addition decreased Bray P-1 significantly in the Hoytville soil only. No significant effects were observed in the Wooster soil. Exchangeable $\mathrm{K}$ in soil treated with residue, glucose and gypsum varied from $883-1280 \mathrm{mg} \mathrm{kg}^{-1}$ in the surface $(0-2 \mathrm{~cm})$ soil layer and decreased with depth. Addition of crop residue generally increased exchangeable $\mathrm{K}$ levels but significant increases occurred only in the $2-4$ and $25-40 \mathrm{~cm}$ soil layers by 23 and $28 \%$, respectively $(\mathrm{P}<0.10)$. Gypsum addition decreased exchangeable $\mathrm{K}$ in all soil layers but significant reductions were observed only below $2 \mathrm{~cm}$ (i.e. the 2-4 and $4-10 \mathrm{~cm}$ soil layers $)(\mathrm{P}<0.10)$.

Concentrations of exchangeable $\mathrm{Ca}$ in soil varied from $1,179-17,180 \mathrm{mg} \mathrm{kg}^{-1}$ in the surface $(0-2 \mathrm{~cm})$ soil layer and decreased with depth like other nutrients. Addition of glucose or residue did not affect exchangeable $\mathrm{Ca}$ levels. However, addition of gypsum caused significant $(\mathrm{P}<0.10)$ increases in exchangeable $\mathrm{Ca}$ in all soil layers, as expected, compared to the control.

Interaction of gypsum with soil type was significant for 0-2, 4-10 and 10-25 cm soil layers. Addition of gypsum increased $\mathrm{Ca}$ concentration significantly in both soils in soil layers 0-2 and 4-10 cm. However in deeper soil layers, the increase in $\mathrm{Ca}$ concentration in Hoytville soil with gypsum addition was significant $(\mathrm{P}<0.10)$, but there were no significant effects of gypsum in the Wooster soil. Exchangeable $\mathrm{Mg}$ concentration in the top soil layer varied from 344-404 mg kg-1. Addition of glucose increased exchangeable $\mathrm{Mg}$ significantly in soil layers 2-4, 4-10, and $10-25 \mathrm{~cm}$ by $7.3,10.0$, and $6.4 \%$, respectively as compared to untreated controls. In contrast to the increase in exchangeable Ca with gypsum application, gypsum caused significant decrease in exchangeable $\mathrm{Mg}$ in the 0-2, 2-4 and 4-10 cm soil layers by 19,17 , and $15 \%$, respectively.

The interaction of glucose with soil type for $\mathrm{Mg}$ was significant for the $4-10 \mathrm{~cm}$ soil layer $(\mathrm{P}<0.10$ and Table 3). Addition of glucose significantly increased exchangeable $\mathrm{Mg}$ in the Hoytville but not the Wooster soil in the 4-10 cm soil layer.

Based upon the concentration of cations in soil, the extractable basic cations ( $\mathrm{Ca}, \mathrm{Mg}$, and $\mathrm{K}$ ) were measured in dried soil after leaching. Extractable basic cations were significantly higher with gypsum application in all soil layers $(\mathrm{P}<0.10)$. Addition of residue also tended to increase extractable basic cations but not significantly. 
Also, Hoytville soil had higher extractable basic cations than Wooster soil due to Hoytville's clay loam texture, which has higher CEC and thus can hold more cations compared with the silt loam texture of the Wooster soil. CEC is also associated with soil organic matter, which was much higher in the Hoytville soil (Table 1).

Interaction of residue with glucose was significant. Addition of residue with glucose increased extractable basic cations significantly compared to residue alone in the 10-25 cm soil layer. Interaction of gypsum with soil types was significant for different soil layers i.e. 0-2, 4-10 and 10-25 cm (Table 3). Addition of gypsum increased extractable basic cations significantly in both soils in the $0-2$ soil layer. However in lower soil layers (i.e. 4-10, 10-25 cm layers), the increase in extractable basic cations with gypsum was significant only in the Hoytville soil.

\subsection{Yield and nutrient concentrations of ryegrass bio- mass}

Cumulative above-ground yield of ryegrass was not significantly affected by addition of residue, glucose, and gypsum. The average above-ground biomass across all treatments was $34.9 \mathrm{~g} \mathrm{pot}^{-1}$. There was a significant difference in cumulative above-ground yield due to soil type $(\mathrm{P}<0.10)$. Ryegrass yield in the Hoytville clay loam soil was almost twice $\left(44.3 \mathrm{~g} \mathrm{pot}^{-1}\right)$ than in the Wooster silt loam soil $\left(25.9 \mathrm{~g} \mathrm{pot}^{-1}\right)$.

The first and last (fifth) harvest of aboveground biomass and the roots of ryegrass were analyzed for total $\mathrm{C}$, total N, P, K, Ca, Mg, S, Al, B, Cu, Fe, Mn, Mo, $\mathrm{Na}$, and $\mathrm{Zn}$ concentrations. In the first harvest (Table 4), concentrations of $\mathrm{N}, \mathrm{Mg}$, and $\mathrm{S}$ decreased $(\mathrm{P}<0.10)$ with the addition of glucose by 7.5, 7.8 and $4.3 \%$, respectively. No significant effects of glucose were observed on concentrations of micronutrients in the first harvest except for Mn (21\% increase) (Table 4), or in concentrations of macronutrients in the last aboveground harvest (Table 4). In the last above-ground harvest, glucose addition increased Mo 21\% (Table 4). All of these values were significantly different from the control $(\mathrm{P}<0.10)$. Moreover, significant differences were observed between the various nutrient concentrations of above- and below-ground biomass harvests of ryegrass grown in two soil types (Tables 4 and 5). There were no significant effects of residue addition on nutrient concentrations neither in above-ground biomass harvest nor in roots.

Addition of gypsum did not significantly affect any nutrient concentration in the above-ground first biomass harvest. No significant effects of treatments on macronutrient concentrations in last above-ground biomass harvest were observed except for gypsum. Gypsum increased $\mathrm{Ca}$ and $\mathrm{S}$ concentrations significantly in the fifth aboveground harvest by 50 and $259 \%$, respectively and decreased $\mathrm{Mg}, \mathrm{Fe}$ and $\mathrm{Al}$ by 13, 79, and $86 \%$, respectively (Table 4). Meriño-Gergichevich et al. (2015) also found that gypsum is used to alleviate $\mathrm{Al}$ from soil. For roots (i.e. below-ground biomass), addition of gypsum significantly increased $\mathrm{Ca}$ by $77 \%$ and $\mathrm{S}$ by $175 \%$ (Table 5). Also in roots, gypsum addition increased Mo significantly by $18 \%$ while decreasing $\mathrm{Mg}, \mathrm{Fe}, \mathrm{Al}$ and $\mathrm{Cu}$ by 26,31 , 37 and $21 \%$, respectively (Table 5) $(\mathrm{P}<0.10)$.

Interaction of glucose with soil type was significant for $\mathrm{N}, \mathrm{P}$, and $\mathrm{Mn}$ in the first above-ground biomass harvest (Table 4). Addition of glucose reduced $\mathrm{N}$ concentration significantly in Hoytville soil, but no significant effects were observed in Wooster soil. Addition of glucose increased Mn significantly in ryegrass in Wooster soil but not Hoytville soil.

Interaction of residue with soil type was significant for $\mathrm{N}$ and $\mathrm{B}$ in the first above-ground biomass harvest and Mo in last above-ground biomass harvest (Table 4).

Addition of residue increased Mo concentration significantly in the last above-ground harvest of ryegrass grown in the Hoytville soil only (Table 4). 
Table 4. Effect of treatments and their significant interactions on nutrient concentrations in first and fifth above-ground biomass harvests.

\begin{tabular}{|c|c|c|c|c|c|c|c|c|c|c|c|c|c|c|c|}
\hline \multirow{2}{*}{$\begin{array}{l}\text { Independent } \\
\text { Variables }\end{array}$} & \multicolumn{15}{|c|}{ Dependent variables } \\
\hline & $\mathrm{C}$ & $\mathbf{N}$ & $\mathbf{P}$ & $\mathrm{K}$ & $\mathrm{Ca}$ & $\mathrm{Mg}$ & $\mathrm{s}$ & $\mathrm{Fe}$ & $\mathrm{Na}$ & $\mathrm{Al}$ & B & $\mathrm{Cu}$ & Mn & Mo & $Z_{n}$ \\
\hline & $\cdots$ & 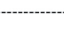 & 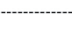 & --- \% & 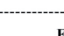 & -ne-n- & -.----- & ass Harv & 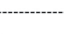 & -........ & -...-.... & $\mathrm{ng} / \mathrm{kg}$-.. & 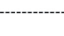 & -a.- & 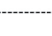 \\
\hline Glucose $(M g / h a)$ & & & & & & A Above- & round Bio & ass Harv & & & & & & & \\
\hline $\begin{array}{l}0 \\
4.5\end{array}$ & $\begin{array}{l}41.8 \\
41.8\end{array}$ & $\begin{array}{l}4.06 \mathrm{a}^{\mathrm{a}} \\
3.75 \mathrm{~b}\end{array}$ & $\begin{array}{l}0.316 \\
0.319\end{array}$ & $\begin{array}{l}4.51 \\
4.35\end{array}$ & $\begin{array}{l}0.766 \\
0.747\end{array}$ & $\begin{array}{l}0.293 \mathrm{a} \\
0.270 b\end{array}$ & $\begin{array}{l}0.280 \mathrm{a} \\
0.268 \mathrm{~b}\end{array}$ & $\begin{array}{l}734 \\
775\end{array}$ & $\begin{array}{l}613 \\
563\end{array}$ & $\begin{array}{l}836 \\
859\end{array}$ & $\begin{array}{l}5.48 \\
5.10\end{array}$ & $\begin{array}{l}6.05 \\
5.71\end{array}$ & $\begin{array}{l}91.5 \mathrm{~b} \\
111 \mathrm{a}\end{array}$ & $\begin{array}{l}2.51 \\
2.58\end{array}$ & $\begin{array}{l}30.7 \\
30.5\end{array}$ \\
\hline $\begin{array}{l}\text { Soil Type } \\
\text { Hoytville } \\
\text { Wooster }\end{array}$ & $\begin{array}{l}42.6 \mathrm{a} \\
40.9 \mathrm{~b}\end{array}$ & $\begin{array}{l}3.79 \mathrm{~b} \\
4.02 \mathrm{a}\end{array}$ & $\begin{array}{l}0.307 \mathrm{~b} \\
0.329 \mathrm{a}\end{array}$ & $\begin{array}{l}4.23 \mathrm{~b} \\
4.63 \mathrm{a}\end{array}$ & $\begin{array}{l}0.663 \mathrm{~b} \\
0.850 \mathrm{a}\end{array}$ & $\begin{array}{l}0.280 \\
0.283\end{array}$ & $\begin{array}{l}0.269 \mathrm{~b} \\
0.280 \mathrm{a}\end{array}$ & $\begin{array}{l}439 \mathrm{~b} \\
1070 \mathrm{a}\end{array}$ & $\begin{array}{l}376 \mathrm{~b} \\
800 \mathrm{a}\end{array}$ & $\begin{array}{l}552 \mathrm{~b} \\
1143 \mathrm{a}\end{array}$ & $\begin{array}{l}3.75 \mathrm{~b} \\
6.83 \mathrm{a}\end{array}$ & $\begin{array}{l}6.23 \mathrm{a} \\
5.52 \mathrm{~b}\end{array}$ & $\begin{array}{l}35.7 \mathrm{~b} \\
167 \mathrm{a}\end{array}$ & $\begin{array}{l}4.21 \mathrm{a} \\
0.88 \mathrm{~b}\end{array}$ & $\begin{array}{l}30.6 \\
30.5\end{array}$ \\
\hline $\begin{array}{l}\text { Glucose }(M g / h a) x \text { Soil } \\
\text { 0/Wooster } \\
\text { 0/Hoytville } \\
\text { 4.5/ Wooster } \\
4.5 / \text { Hoytville }\end{array}$ & $:^{\circ}$ & $\begin{array}{l}4.04 \mathrm{a} \\
4.08 \mathrm{a} \\
4.00 \mathrm{a} \\
3.51 \mathrm{~b}\end{array}$ & $\begin{array}{l}0.317 \mathrm{ab} \\
0.316 \mathrm{ab} \\
0.340 \mathrm{a} \\
0.298 \mathrm{~b}\end{array}$ & $\vdots$ & $\vdots$ & $:$ & $\vdots$ & 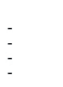 & $\overline{5}$ & $\begin{array}{l}\overline{-} \\
\overline{-}\end{array}$ & $\overline{-}$ & $\overline{-}$ & $\begin{array}{l}149 \mathrm{~b} \\
34.1 \mathrm{c} \\
185 \mathrm{a} \\
37.3 \mathrm{c}\end{array}$ & : & $\vdots$ \\
\hline $\begin{array}{l}\text { Residue }(\mathbf{M g} / \mathrm{ha}) \text { x Soil } \\
\text { 0/Wooster } \\
\text { 0/Hoytville } \\
\text { 13.4/Wooster } \\
\text { 13.4/ Hoytville }\end{array}$ & $\begin{array}{l}- \\
\overline{-} \\
\overline{-}\end{array}$ & $\begin{array}{l}4.18 \mathrm{a} \\
3.74 \mathrm{~b} \\
3.86 \mathrm{ab} \\
3.84 \mathrm{ab}\end{array}$ & $\begin{array}{l}- \\
5\end{array}$ & : & : & : & $\vdots$ & $\begin{array}{l}- \\
\overline{-}\end{array}$ & $\begin{array}{l}- \\
\overline{-}\end{array}$ & $\begin{array}{l}- \\
\overline{-} \\
-\end{array}$ & $\begin{array}{l}5.62 \mathrm{ab} \\
3.88 \mathrm{~b} \\
8.03 \mathrm{a} \\
3.62 \mathrm{~b}\end{array}$ & $\begin{array}{l}\overline{-} \\
\overline{-}\end{array}$ & $\overline{-}$ & $\overline{-}$ & : \\
\hline $\begin{array}{l}\text { Gypsum }(\mathrm{Mg} / \mathrm{ha}) \cdot \boldsymbol{x} \text { Soil } \\
\text { 0/Wooster } \\
\text { 0/Hoytville } \\
\text { 26.9/ Wooster } \\
\text { 26.9/ Hoytville }\end{array}$ & $\begin{array}{l}- \\
\vdots\end{array}$ & $\begin{array}{l}4.11 \mathrm{a} \\
3.69 \mathrm{~b} \\
3.93 \mathrm{ab} \\
3.90 \mathrm{ab}\end{array}$ & $\vdots$ & $\vdots$ & $\vdots$ & $:$ & $:$ & 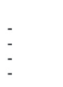 & $\begin{array}{l}- \\
\overline{-}\end{array}$ & $\overline{-}$ & $\overline{-}$ & $\begin{array}{l}6.07 \mathrm{ab} \\
6.08 \mathrm{ab} \\
4.98 \mathrm{~b} \\
6.39 \mathrm{a}\end{array}$ & : & : & $\vdots$ \\
\hline & & & & & & h Above- & round Bio & Iass Harv & & & & & & & \\
\hline $\begin{array}{l}\text { Glucose }(M g / h a) \\
\quad 0 \\
4.5\end{array}$ & $\begin{array}{l}41.2 \\
43.0\end{array}$ & $\begin{array}{l}3.65 \\
3.57\end{array}$ & $\begin{array}{l}0.312 \\
0.292\end{array}$ & $\begin{array}{l}3.40 \\
3.36\end{array}$ & $\begin{array}{l}1.56 \\
1.91\end{array}$ & $\begin{array}{l}0.402 \\
0.400\end{array}$ & $\begin{array}{l}0.679 \\
0.366\end{array}$ & $\begin{array}{l}551 \\
784\end{array}$ & $\begin{array}{l}1502 \\
1345\end{array}$ & $\begin{array}{l}574 \\
838\end{array}$ & $\begin{array}{l}20.2 \\
23.8\end{array}$ & $\begin{array}{l}7.55 \\
7.14\end{array}$ & $\begin{array}{l}343 \\
337\end{array}$ & $\begin{array}{l}3.53 \mathrm{~b} \\
4.26 \mathrm{a}\end{array}$ & $\begin{array}{l}54.3 \mathrm{a} \\
42.4 \mathrm{~b}\end{array}$ \\
\hline $\begin{array}{l}\text { Gypsum }(M g / h a) \\
0 \\
26.9\end{array}$ & $\begin{array}{l}43.2 \\
41.1\end{array}$ & $\begin{array}{l}3.63 \\
3.59\end{array}$ & $\begin{array}{l}0.303 \\
0.301\end{array}$ & $\begin{array}{l}3.41 \\
3.35\end{array}$ & $\begin{array}{l}1.10 \mathrm{~b} \\
1.65 \mathrm{a}\end{array}$ & $\begin{array}{l}0.429 \mathrm{a} \\
0.373 \mathrm{~b}\end{array}$ & $\begin{array}{l}0.228 \mathrm{~b} \\
0.818 \mathrm{a}\end{array}$ & $\begin{array}{l}1099 \mathrm{a} \\
236 \mathrm{~b}\end{array}$ & $\begin{array}{l}1555 \\
1292\end{array}$ & $\begin{array}{l}1236 \mathrm{a} \\
176 \mathrm{~b}\end{array}$ & $\begin{array}{l}24.1 \\
19.9\end{array}$ & $\begin{array}{l}7.68 \\
7.00\end{array}$ & $\begin{array}{l}401 \\
278\end{array}$ & $\begin{array}{l}3.90 \\
3.88\end{array}$ & $\begin{array}{l}50.9 \\
45.7\end{array}$ \\
\hline $\begin{array}{c}\text { Soil Type } \\
\text { Hoytville } \\
\text { Wooster }\end{array}$ & $\begin{array}{l}42.3 \mathrm{a} \\
39.9 \mathrm{~b}\end{array}$ & $\begin{array}{l}3.66 \\
3.57\end{array}$ & $\begin{array}{l}0.302 \\
0.303\end{array}$ & $\begin{array}{l}3.39 \\
3.37\end{array}$ & $\begin{array}{l}1.22 \\
1.53\end{array}$ & $\begin{array}{l}0.433 \mathrm{a} \\
0.369 \mathrm{~b}\end{array}$ & $\begin{array}{l}0.373 \\
0.673\end{array}$ & $\begin{array}{l}297 \mathrm{~b} \\
1038 \mathrm{a}\end{array}$ & $\begin{array}{l}938 \mathrm{~b} \\
1909 \mathrm{a}\end{array}$ & $\begin{array}{l}319 \mathrm{~b} \\
1093 \mathrm{a}\end{array}$ & $\begin{array}{l}18.2 \mathrm{~b} \\
25.8 \mathrm{a}\end{array}$ & $\begin{array}{l}8.54 \mathrm{a} \\
6.14 \mathrm{~b}\end{array}$ & $\begin{array}{l}92.6 \mathrm{~b} \\
587 \mathrm{a}\end{array}$ & $\begin{array}{l}6.69 \mathrm{a} \\
1.09 \mathrm{~b}\end{array}$ & $\begin{array}{l}46.6 \\
50.0\end{array}$ \\
\hline $\begin{array}{l}\text { Residue }(\mathbf{M g} / \mathrm{ha}) \text { x Soil } \\
\text { 0/Wooster } \\
\text { 0/Hoytwille } \\
\text { 13.4/Wooster } \\
\text { 13.4/ Hoytville }\end{array}$ & $\begin{array}{l}- \\
\vdots\end{array}$ & $\begin{array}{l}- \\
-\end{array}$ & $\vdots$ & $:$ & $\vdots$ & $:$ & $\vdots$ & 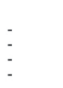 & $\begin{array}{l}- \\
\overline{-}\end{array}$ & $\overline{-}$ & $\overline{-}$ & $\begin{array}{l}- \\
\vdots\end{array}$ & : & $\begin{array}{l}0.98 \mathrm{c} \\
6.75 \mathrm{~b} \\
0.85 \mathrm{c} \\
7.83 \mathrm{a}\end{array}$ & $:$ \\
\hline $\begin{array}{l}\text { Gypsum }(\mathrm{Mg} / \mathrm{ha}) \times \text { Soil } \\
\text { 0/Wooster } \\
\text { 0/Hoytville } \\
\text { 26.9/ Wooster } \\
\text { 26.9/ Hoytville } \\
\end{array}$ & $\begin{array}{l}- \\
-\end{array}$ & :- & 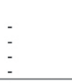 & $:$ & $:$ & $:$ & $\vdots$ & $\begin{array}{l}1786 \mathrm{a} \\
412 \mathrm{~b} \\
289 \mathrm{~b} \\
182 \mathrm{~b}\end{array}$ & $\begin{array}{l}- \\
-\end{array}$ & $\begin{array}{l}1978 \mathrm{a} \\
494 \mathrm{ab} \\
208 \mathrm{~b} \\
144 \mathrm{~b}\end{array}$ & $\begin{array}{l}- \\
-\end{array}$ & : & $:$ & $\begin{array}{l}1.29 \mathrm{~b} \\
6.26 \mathrm{a} \\
0.895 \mathrm{~b} \\
7.13 \mathrm{a}\end{array}$ & $:$ \\
\hline
\end{tabular}

${ }^{a}$ Means in a column for an independent variable that are followed by the same letter or no letter are not statistically different at the $\mathrm{P}<0.10$ level of significance.

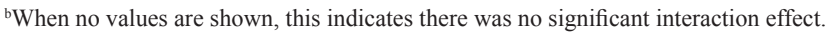

Interaction of glucose with gypsum for $\mathrm{Mg}$ was significant in the below-ground harvest (Table 5). Addition of gypsum alone or in combination with glucose reduced $\mathrm{Mg}$ significantly as compared to glucose alone and control treatments. Gypsum with soil type interaction was also significant for various nutrients in first and last above-ground biomass and below-ground harvest (Tables 4 and 5). Interaction was significant for $\mathrm{N}$ and $\mathrm{Cu}$ in the first above-ground harvest; $\mathrm{Fe}, \mathrm{Al}$ and $\mathrm{Mo}$ in the last above-ground harvest, and $\mathrm{K}, \mathrm{Ca}$, $\mathrm{Mg}$ and $\mathrm{S}$ in the below-ground harvest $(\mathrm{P}<0.10)$.
In the last above-ground harvest, addition of gypsum behaved differently in the two soil types for Fe and Al. Addition of gypsum reduced $\mathrm{Fe}$ and $\mathrm{Al}$ concentrations significantly in ryegrass in Wooster soil, but not in Hoytville soil. For roots, addition of gypsum decreased $\mathrm{Mg}$ and $\mathrm{K}$ concentrations significantly in Hoytville soil and reduced $\mathrm{K}$ but not $\mathrm{Mg}$ concentrations in Wooster soil (Table 5). The addition of gypsum in both soil types increased $\mathrm{Ca}$ and $\mathrm{S}$ significantly as compared to their untreated controls (Table 5). 
Table 5. Effect of treatments and their significant interactions on nutrient concentrations in below-ground biomass.

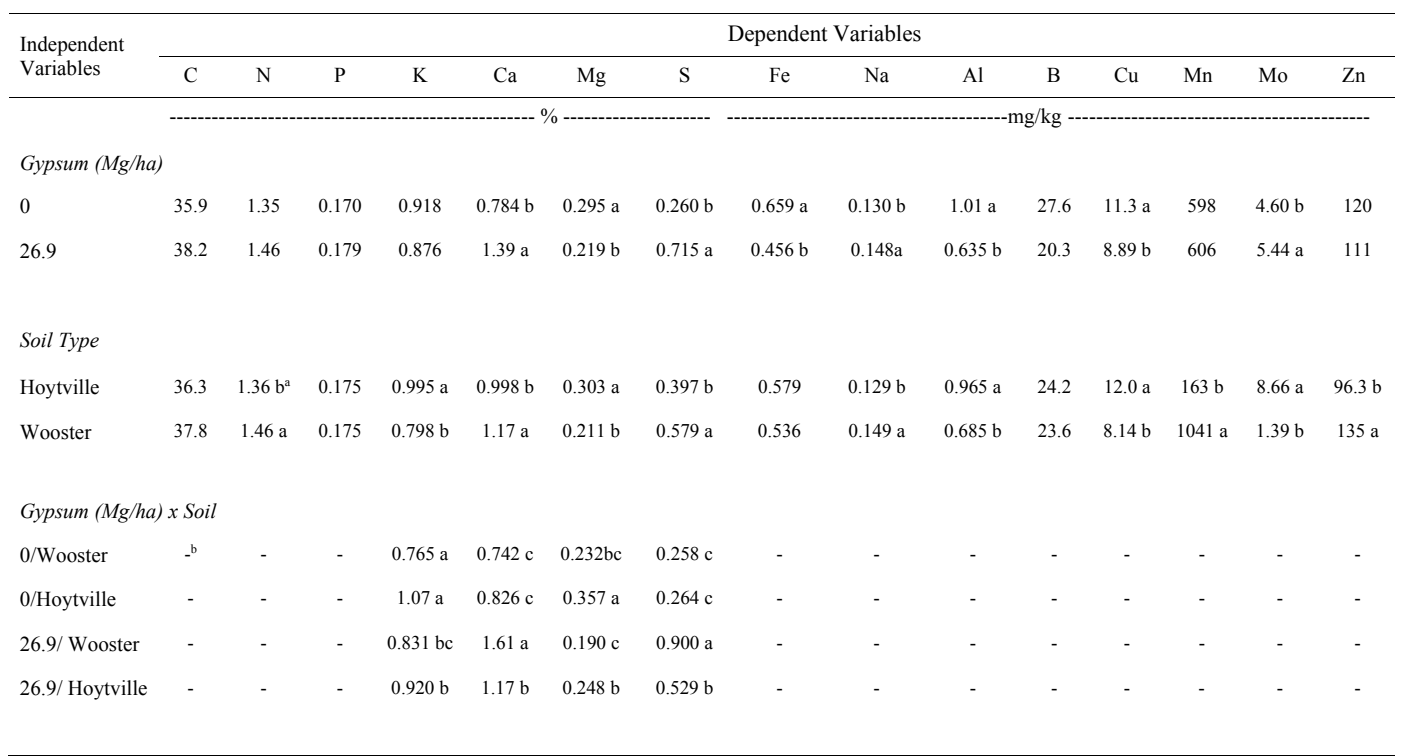

${ }^{a}$ Means in a column for an independent variable that are followed by the same letter or no letter are not statistically different at the $\mathrm{P}<0.10$ level of significance.

${ }^{b}$ When no values are shown, this indicates there was no significant interaction effect.

\section{Discussion}

\subsection{Soil properties}

The two soil types resulted in significant differences in various soil nutrient concentrations and their uptake by ryegrass. The amendments added to soil also caused differences in soil and plant parameters measured. For example, addition of plant residues increased soil $\mathrm{N}$ significantly due to release of $\mathrm{N}$ upon decomposition of residues in soil. However, addition of gypsum reduced the concentration of soil $\mathrm{N}$ significantly which was attributed to displacement of $\mathrm{NH}_{4}{ }^{+}$ from exchangeable sites by $\mathrm{Ca}^{2+}$ supplied by the gypsum addition. Glucose addition lowered the soil $\mathrm{pH}$ significantly in the lower layers. Increased soil $\mathrm{pH}$ values with addition of residues were attributed to the release of basic cations during position (Pocknee and
Sumner, 1997). Soil properties such as moisture content, texture, $\mathrm{pH}$, available $\mathrm{N}$, and indigenous organic matter have great impacts on the decomposition of organic matter (Jarvis et al., 1996) and thus on soil $\mathrm{pH}$ changes. Increasing the acidity of layers with addition of organic matter has been usually found below $10 \mathrm{~cm}$ due to the downward movement of $\mathrm{H}^{+}$ (Williams, 1980). Addition of gypsum increased soil $\mathrm{pH}$ only in the lowest soil layer i.e. $25-40 \mathrm{~cm}$. Soil $\mathrm{pH}$ may increase after gypsum application due to the displacement of $\mathrm{Al}^{3+}$ and $\mathrm{H}^{+}$from the cation exchange sites, which are then rapidly leached from the soil due to the presence of $\mathrm{Ca}^{2+}$ (Alva et al., 1988). Addition of residue and gypsum alone or in combination also increased soil $\mathrm{pH}$ significantly as compared to the untreated control, due to release of cations upon decomposition of residue or dissolution of gypsum. 
Interaction of gypsum with soil types was significant and addition of gypsum in Hoytville soil increased soil $\mathrm{pH}$ significantly in all soil layers as compared to Hoytville control. This is attributed to displacement of two $\mathrm{H}^{+}$from exchange sites with one $\mathrm{Ca}^{2+}$ supplied from gypsum addition. However, this reaction seemed to be only important in the Hoytville soil due to high clay content associated with its finer texture that held more $\mathrm{H}^{+}$that could then be displaced by $\mathrm{Ca}$ and thus increased soil $\mathrm{pH}$.

Increased Bray P-1 levels with residue addition was due to $\mathrm{P}$ being applied to soil from residue and also from $\mathrm{P}$ fertilizer applied to all soil columns. Similar results of significant increases in organic $\mathrm{C}$ and $\mathrm{N}$, and available $\mathrm{P}$ and $\mathrm{K}$ were also observed with the addition of crop residue in conjunction with NPK fertilizers in the $0-15$ and $15-30 \mathrm{~cm}$ soil layers as compared to the control (Walia et al., 2010). However, addition of glucose decreased Bray P-1 in the deepest layer due to significant loss of $\mathrm{P}$ in leachate as addition of glucose increases microbial activity, and solubilization of $\mathrm{P}$. There are numerous reports of soil microorganisms that can solubilize mineral P (Alexander, 1977). In contrast, gypsum reduced Bray P-1 by $40 \%$ in the top layer of soil. These results suggested that gypsum stimulates the formation of less soluble Ca-P compounds by reacting with readily available soil phosphorus (Favaretto et al., 2006).

Exchangeable $\mathrm{K}$ levels increased in soil with addition of residues. This resulted from addition of $\mathrm{K}$ in the crop residues that had a $\mathrm{K}$ concentration of 8560 $\mathrm{mg} \mathrm{kg}{ }^{-1}$ (Table 2). If crop uptake of $\mathrm{K}$ occurs and these residues are removed from soil before they can be decomposed, there is a decrease in exchangeable K (Janssen and Whitney, 1995). The reduced K concentration in soil from gypsum treated soil columns was attributed to displacement of $\mathrm{K}^{+}$by $\mathrm{Ca}^{2+}$ from exchangeable sites. In contrast to the gypsum effect on $\mathrm{K}$ concentrations, gypsum increased soil exchangeable
$\mathrm{Ca}^{2+}$ in all soil layers. Gypsum is considered a moderately soluble source of $\mathrm{Ca}$ and the $\mathrm{Ca}$ in gypsum can be translocated downward into the soil profile (Farina et al., 2000b; Toma et al., 1999).

Exchangeable $\mathrm{Mg}$ in soil was decreased significantly with gypsum additions. The $\mathrm{Ca}$ in the gypsum displaced $\mathrm{Mg}$ from exchangeable sites. These results suggest that Mg may need to be monitored after gypsum application to maintain an adequate $\mathrm{Mg}$ fertility level, especially in sandy soils (Sumner, 1993). Other studies with gypsum amendment to soil subjected to leaching have also demonstrated reductions in exchangeable $\mathrm{Mg}$, mainly in the upper part of the profile (Farina et al., 2000b; Toma et al., 1999; Shainberg et al., 1989). The behavior of exchangeable Mg was different from other elements within the soil profile as its concentration increased with soil depth while the concentrations of other nutrients decreased with increase in soil depth. The higher values of $\mathrm{Mg}$ in the lowest layers are result of $\mathrm{Mg}$ mobilization and subsequent translocation, from the top soil layers to the lower soil layers (Grzebisz, 2011).

The interaction of glucose with soil type for $\mathrm{Mg}$ was found to be significant with addition of glucose resulting in a significant increase in exchangeable $\mathrm{Mg}$ concentrations only in the Hoytville soil. The Hoytville soil has higher clay content than Wooster soil. Thus the slight increase in acidity caused by glucose addition had a lesser effect on the Mg concentrations because the clay, with its greater CEC activity, could better hold on to the displaced $\mathrm{Mg}$.

\subsection{Biomass of ryegrass and their nutrient concentra- tions}

No significant effects of residue, glucose, or gypsum were observed on yield of ryegrass. The decrease in concentrations of nutrients in ryegrass is considered mostly due to glucose being a readily available $\mathrm{C}$ 
source that could lead to immobilization of plant nutrients by microorganisms. Increase in Mo concentrations with glucose was attributed to a slight increase in $\mathrm{pH}$ in the surface $(0-2 \mathrm{~cm})$ soil layer only as compared to control, which increases the availability of Mo and thus its uptake by plants. The acidity caused by glucose additions in lower layers below $2 \mathrm{~cm}$ might have resulted in increased availability of Mn and its uptake by ryegrass.

The increased $\mathrm{Ca}$ and $\mathrm{S}$ in last above-ground and roots harvest with gypsum addition resulted from gypsum being an excellent source of $\mathrm{Ca}$ and $\mathrm{S}$ when applied to soil. Concentration of $\mathrm{Mg}$ in roots was decreased with addition of gypsum both when applied alone or in combination with glucose. Calcium ions from gypsum and $\mathrm{H}^{+}$from the increased acidity caused by the glucose replaced $\mathrm{Mg}$ on exchange sites and this $\mathrm{Mg}$ was lost from soil in leachate water and thus reduced $\mathrm{Mg}$ uptake by roots.

The interaction of gypsum with soil types significantly affected uptake of $\mathrm{K}, \mathrm{Ca}, \mathrm{Mg}$, and $\mathrm{S}$ in roots. For example, the increased $\mathrm{Ca}$ from gypsum addition replaced $\mathrm{Mg}$ from exchange complex in the soil solution and was then lost by leaching, thus reducing $\mathrm{Mg}$ uptake. This effect of gypsum on $\mathrm{Mg}$ uptake for plants growing in the Hoytville soil was greater compared to the Wooster soil. It is commonly known that the uptake of $\mathrm{Mg}$ is strongly influenced by the availability of other cations like Ca and K (Römheld and Kirkby, 2007). The significant reduction in Al concentrations in roots was attributed to increased $\mathrm{Ca}$ levels with gypsum addition on exchangeable sites and to positive competition for uptake between $\mathrm{Al}$ and $\mathrm{Ca}$. This is consistent with reports of decreased concentrations of $\mathrm{Al}$ in soil by gypsum application (Shainberg et al., 1989). FGD gypsum can ameliorate the phytotoxic conditions arising from excess soluble aluminum in acid soils by reacting with $\mathrm{Al}^{3+}$ and forming aluminum sulfate, thus removing it from the soil solution and greatly reducing its toxic effects (Shainberg et al., 1989). By over $\neg$ coming the effects of subsurface aluminum toxicity, gypsum can improve deep rooting and increase crop uptake of water and nutrients from subsoil layers. This is especially important in the dry season of arid areas, and a positive response to FGD gypsum is often greatest in moisture stress conditions (Chen and Dick, 2011).

The concentration of $\mathrm{Fe}$ in last above-ground biomass harvest and in roots decreased significantly with gypsum as compared to the control because of improved infiltration of water with the addition of gypsum. This also improves aeration of the soil because as water flows through soil, it pull oxygen into the pores behind it. This prevents the development of reducing redox microenvironments where Fe available can be increased as the availability of Fe increases under reduced conditions.

Uptake of copper by roots was reduced significantly with gypsum inclusion, attributed to an increase in $\mathrm{pH}$ by gypsum addition at soil depths below $10 \mathrm{~cm}$ that reduced $\mathrm{Cu}$ availability and uptake. Yodthongdee et al. (2013) reported that concentrations of the micronutrients $(\mathrm{Cu}$ and $\mathrm{Zn})$ in plants were decreased with increasing application rates of FGD gypsum. The interaction of gypsum with soil type was significant for $\mathrm{Cu}$ in the first above-ground biomass harvest. High uptake of $\mathrm{Cu}$ by ryegrass in Hoytville soil was attributed to more organic matter and clay content in Hoytville soil, which can hold more $\mathrm{Cu}\left(\mathrm{as}^{2+}\right)$ on the surface of clay minerals or in association with organic matter. Soil properties such as $\mathrm{pH}$, soil organic matter content (SOM), cation exchange capacity (CEC), and soil texture all are known to influence soil $\mathrm{Cu}$ concentration and thus plant uptake (Kabata-Pendias and Pendias, 2001). The uptake of Mo in last aboveground biomass and roots was significantly higher in Hoytville soil than Wooster soil because of higher $\mathrm{pH}$ for Hoytville in all soil layers. 
Also the clay texture of Hoytville soil affects Mo availability as the availability of Mo for plant growth is strongly dependent upon soil $\mathrm{pH}$ and concentration of adsorbing oxides (e.g. Fe oxides) (Kaiser et al., 2005). In alkaline soils, Mo becomes more soluble and is accessible to plants mainly in its anion form as $\mathrm{MoO}_{4}^{-}$.

\section{Conclusions}

Addition of crop residues improved soil chemical properties and increased nutrient uptake by ryegrass, but the changes were not always statistically significant. Soil chemical properties improved by residue addition were increased total $\mathrm{N}, \mathrm{pH}$, Bray P-1 and exchangeable $\mathrm{K}$ and $\mathrm{Mg}$. Glucose addition did not improve the availability and uptake of macro- and micronutrients except for Mo uptake that was increased. Gypsum increased soil $\mathrm{pH}$ in deeper layers and exchangeable $\mathrm{Ca}$ in all soil layers, and increased $\mathrm{Ca}$ and $\mathrm{S}$ uptake into plants indicates gypsum is an excellent source of these nutrients. Bray P-1 decreased in the surface $(0-2 \mathrm{~cm})$ soil layer with addition of gypsum and thus gypsum amendment can have beneficial environmental impacts because release of soluble $\mathrm{P}$ to water is a major cause of eutrophication. Uptake of $\mathrm{Mg}$ and $\mathrm{Al}$ by ryegrass decreased due to abundance of $\mathrm{Ca}$. The aboveground biomass was not significantly affected by addition of residue, glucose, and gypsum. Addition of residues and gypsum, apart from improving soil properties, can result in better crop nutrition and these amendments can contribute towards improving soil and crop quality.

\section{Acknowledgments}

"Funding for this study was provided by the USDANIFA, Award No. 2011-68002-30190 “Cropping Systems Coordinated Agricultural Project (CAP): Climate Change, Mitigation, and Adaptation in Corn- based Cropping Systems" and by state and federal funds appropriated to The Ohio State University and The Ohio Agricultural Research and Development Center."

\section{References}

Alexander, M. 1977. Introduction to soil microbiology. Wiley New York.

Alva, A.K., Summer, M.E., Noble, A.D. 1988. Alleviation of aluminum toxicity byphosphogypsum. Commun. Soil Sci. Plant Anal. 9, 385-403.

Amato, M., Ladd, J.N. 1992. Decomposition of 14Clabelled glucose and legume material in soils: Properties influencing the accumulation of organic residue $\mathrm{C}$ and microbial biomass $\mathrm{C}$. Soil Bio. Biochem. 24, 455-464.

American Coal Ash Association 2016. coal combustion product (CCP) production and use survey. Am. Coal Ash Assoc., Aurora, CO.

Batool, A., Taj, S., Rashid, A., Khalid, A., Qadeer, S., Saleem, A.R., and Ghufran, M.A. 2015. Potential of soil amendments (biochar and gypsum in increasing water use efficiency of $\mathrm{Abel}$ moschus esculentus L. Moench. Front. Plant Sci. 5: 733.

Black, A.L. 1973. Soil property changes associated with crop residue management in a wheat-fallow rotation. Soil Sci. Soc. Am. Proc. 37, 943-946.

Chen, L., Dick, W.A. 2011. Gypsum as an agricultural amendment: General use guidelines. The Ohio State University Extension, Columbus. http:// ohioline.osu.edu/b945/index.html.

Day, P.R. 1965. Particle fractionation and particlesize analysis. p. 545-567. In:CA Black etal. (ed.) Methods of soil analysis, Part I. Agron. 9, 545-567. 
Dick, W.A., Huo, Y., Stehouwer, R.C., Bigham, J.M., Wolfe, W.E., Adraiano, D., Beeghly, J.H., Haefner, R.J. 2006. Beneficial uses of flue gas desulfuration by products; Examples and case studies of land application.pp 505-536. In J.F. Power and W.A. Dick (ed.) Land application of agricultural , industrial, and municipal by products. SSSA Book Series.6, Madison, WI.

Farina, M.P.W., Channon, P., Thibaud, G.R. 2000b. A comparison of strategies for Ameliorating subsoil acidity: I. Long-term soil effects. Soil Sci.Soc. Am. J. 64, 652658.

Favaretto, N., Norton, L.D., Joern, B.C., Brouder, S.M. 2006. Gypsum amendment and exchangeable calcium and magnesium affecting phosphorus and nitrogen in runoff. Soil Sci.Soc. Am. J. 70, 1788-1796.

Frank, K., Beegle, D., Denning, J. 1998. Phosphorus, pp 21-23. In: Recommended chemical soil test procedures for the North Central Region.NCR Publication No. 221.Missouri Agricultural Experiment Station, Columbia, MO, USA.

Grzebisz, W. 2011. Magnesium-food and human health. J. Elem. 16, 299-323.

Jarvis, S.C., Stockdale, E.A., Shepherd, M.A., Powlson, D.S. 1996. Nitrogen mineralization in temperate agricultural soils: Processes and measurements. Adv.Agron. 57, 187-235.

Kabata-Pendias, A., Pendias, H. 2001. Trace Elements in Soils and Plants. CRC, Boca Raton.

Kaiser, B.N., Gridley, K.L., Brady, J.N., Phillips, T., Tyerman, S.D. 2005. The role of molybdenum in agricultural plant production. Ann. Bot. 96, 745-754.

Lindau, C.W., Wickersham, P., DeLaune, R.D., Collins, J.W., Bollick, P.K., Scott, M., Lambremont, E.N. 1998. Methane and nitrous oxide evolution and ${ }^{15} \mathrm{~N}$ and ${ }^{226} \mathrm{Ra}$ uptake as affected by application of gypsum and phosphogypsum to Louisiana rice. Agric.Ecosys. Environ.68, 165-173.
Martens, D.A. 2000b. Management and crop residue influence soil aggregate stability. J.Environ. Qual. 29, 723-727.

Meriño-Gergichevich, C., Ondrasek, G., Zovko, M., Šamec, D., Alberdi, M., Reyes- Díaz, M. 2015. Comparative study of methodologies to determine the antioxidant capacity of Al-toxified blueberry amended with calcium sulfate. J. Soil Sci. Pl. Nut.15 (4), 965-978.

Minitab Inc. 2007. Minitab®Release 16. Minitab Inc, State College, PA, USA.

Nelson, D.W., Sommers, L.E. 1996. Total carbon, organic carbon and organic matter. In: 'Methods of soil analysis. Part 3. Chemical methods'. pp 961-1010. (Eds. D.I. Sparks et al.) (Soil Science Society of America: Madison, USA).

Ogbodo, E.M. 2011. Effect of crop residue on soil chemical properties and rice yield on anultisol at Abakaliki, Southeastern Nigeria. World J. Agric. Sci. 7, 13-18.

Pocknee, S., Sumner, M.E. 1997. Cation and nitrogen contents of organic matter determine its soil liming potential. Soil Sci.Soc. Am. J. 61, 86-92.

Römheld, V., Kirkby, E.A. 2007. Magnesium functions in crop nutrition and yield. Proceedings of a conference in Cambridge pp 151-171.

Saroa, G.S., Lal, R. 2003. Soil restorative effects of mulching on aggregation and carbon sequestration in a Miamian soil in Central Ohio. Land Degrad. Dev. 14, 481-493.

Shainberg, I., Sumner, M.E., Miller, W.P., Farina, M.P.W., Pavan, M.A., Fey, M.V. 1989. Use of gypsum on soils: A review. Adv. Soil Sci. 9, 1-111.

Sumner, M.E. 1993. Gypsum and acid soils: The world scene. Advan. Agron. 51, 1-32.

Syed-Omar, S.R., Sumner, M.E. 1991. Effect of gypsum on soil potassium and magnesium status and growth of alfalfa. Commun. Soil Sci. Plant Anal. 22, 19-20. 
Toma, M., Sumner, M.E., Weeks, G., Saigusa, M. 1999. Long-term effects of gypsum on crop yield and subsoil chemical properties. Soil Sci. Soc. Am. J.63, 891-895 doi:10.2136/sssaj1999.634891x.

Walia, M.K., Walia, S.S., Dhaliwal, S.S. 2010. Longterm effect of integrated nutrient management of properties of Typic Ustochrept after 23 cycles of an irrigated rice (Oryza sativa L.) - wheat (Triticum aestivum L.) system. J. Sustain. Agric. 34, 724-743.

Watson, M.E., Brown, J.R. 1998. pH and Lime Requirement, pp 13-16. In: Recommended chemical soil test procedures for the North Central Region. NCR Publication No. 221.Missouri Agricultural Experiment Station, Columbia, MO, USA.
Warncke, D., Brown, J.R. 1998. Potassium and other basic cations, pp 31-33. In: Recommended chemical soil test procedures for the North Central Region. NCR Publication No. 221. Missouri Agricultural Experiment Station, Columbia, MO, USA.

Williams, C.H. 1980. Soil acidification under clover pasture. Aust. J. Exp.Agric. 20, 561-567.

Yodthongdee, Y., Sooksamiti, P., Jakmunee, J., Lapanantnoppkhun, S. 2013. Uptake of nutrients in vegetables grown on FGD-gypsum amended soils. Oriental J. Chem. 29, 1027-1032. 